\title{
20
}

\section{PRIVATE RENTAL HOUSING IN CANADA'S FOUR LARGEST METROPOLITAN AREAS}

\section{Trends and Prospects}

\author{
J. David Hulchanski
}

\section{Introduction}

Canada is a nation of homeowners. About $68 \%$ of households are owners and $28 \%$ are tenants in the PRS. In Canada, $96 \%$ of households either buy or rent in the housing market. Canada has one of the smallest non-market social housing sectors among comparator Western nations, at about $4 \%$ of the nation's housing stock compared to $10 \%$ to $30 \%$ in much of western and northern Europe (Crook \& Kemp 2014; Housing Europe 2019; van der Heijden 2013). The PRS is a significant segment of Canada's housing market and housing system (Gibb et al., 2019).

The housing system here refers to the "full range of inter-relationships between all of the actors (individual and corporate), and institutions involved in the production, consumption and regulation of housing" (Bourne 1981:12). Slightly more than a quarter of Canada's households depend on the PRS for the provision and maintenance of their housing. The PRS plays an important role by providing an option for households unable or unwilling to become homeowners or for households unable to access social housing due to ineligibility or long waiting lists (August \& Walks 2018; Bourne 1986; Crook 1998; Hulchanski 1988; Hulchanski \& Shapcott 2004; Miron 1995; Steele 1993; Suttor 2009; Tsenkova \& Witwer 2011; Wolfe 1998).

Yet since the mid-1980s in Canada, the supply of new and the rehabilitation of ageing PRS housing have been largely ignored by federal and most provincial governments (Bacher 1993; Chisholm \& Hulchanski 2019; Crook 1998; Pomeroy \& Falvo 2013; Suttor 2009, 2016). There is no explicit public policy about the role of the PRS, and there is very little public funding for new supply, especially in comparison to subsidies provided to homeownership. As a result, Canada has an ageing stock of rental housing and a growing share of units in need of rehabilitation. Households living in rental housing affected by disrepair due to ageing and neglect are disproportionately from lower-income disadvantaged population groups, including racialized minorities, Indigenous people, female-led single-parent families, the elderly, and people with disabilities (Bunting, Walks \& Filion, 2004).

Canada's PRS has not been ignored by Canadian and global speculators and investors (August \& Walks 2018; Kalman-Lamb 2017; Ley 2015; Walks 2014a, 2014b; Walks \& Clifford, 2015). Since the 1990s, there is a new reality for housing systems in many nations, the hyper-commodification of housing (Aalbers, 2016). A transnational class of super-rich housing investors is disrupting our understanding of local housing markets. Residential land and 
housing were always commodities, but mainly as a very localized commodity in a market focused on meeting the actual residential accommodation needs of households in a particular geography. The change in the macro context in which the housing system operates, producing the hyper-commodification, are powerful financial and political forces and dynamics we have come to generally refer to as deregulation, financialization, and globalization (Madden \& Marcuse, 2016:52-62).

Deregulation, which mainly means different regulations over housing and not necessarily fewer regulations, removes, changes, and/or introduces regulations that do not impede the commodity aspect of real estate (Boudreau et al., 2009; Hackworth \& Moriah, 2006). The financialization of housing has converted, with the help of the changed regulations, housing into large-scale globally traded financialized instruments ("products") to be bought, sold, and speculated with, including use for money laundering and tax evasion. The global financialization of housing refers to the easy flow of wealth networks that seek quality real estate assets in prosperous localities in safe countries (Ley, 2015; Madden \& Marcuse, 2016; Rogers \& Koh, 2017; Walks, 2014b).

Housing, particularly in the larger metropolitan areas, is no longer just housing - a physical structure where people in a particular locale live. There is now more housing that is used for purposes other than as a main residence, something Doling and Ronald (2019) term as "not for housing" housing (NFHH). There are four types of NFHH that are now very common: second homes, foreign buying of investment properties, houses as hotels, and houses as offices (Doling \& Ronald, 2019:24-25; Grisdale 2019). These subcategories of NFHH are not based on the housing needs of the local housing market or even local or national economic conditions. Canada's real estate is particularly attractive to global investors and speculators. There are few regulations on ownership and very weak disclosure requirements about who the beneficial owners are or where the money came from. In addition, real estate investment and speculation benefits from the fact that the 2008-2009 global financial crisis had limited impact on Canada's housing system, enhancing the sense of investment safety and stability (Walks, 2014a).

This chapter focuses on macro-social and economic issues and trends affecting three facets of the PRS: the existing supply and potential new supply, the quality of the existing rental stock, and the socio-economic status of tenants in the PRS. The focus is on the four largest census metropolitan areas (CMAs): Montréal, Toronto, Calgary, and Vancouver. These have a population of 14 million people, $40 \%$ of Canada's population, housing $44 \%$ of Canada's renter households (2016 Census). Montréal and Toronto alone house one-third of Canada's renters.

\section{Definition: What Is the Private Rented Sector?}

When the term "private rented sector" (PRS) is used it might be easy to assume there is general agreement on what this part of a nation's housing system actually is, that is, what are the boundaries between private for-profit and social (public and non-profit) rental. Housing tenure, the terms and conditions (rights and responsibilities), legal and cultural, by which housing is owned, occupied, and maintained, is very different between nations and even somewhat different between provinces and territories in Canada. The PRS can be defined based on key attributes such as the forms of subsidization, differences in ownership, the method by which rents are determined, and/or the bundle of property rights. The definition used here, however, is that provided in Haffner et al.: "rented housing that is not allocated according to socially determined need" (Haffner et al., 2010; Granath Hansson \& Lundgren, 2019). This provides a common basic fact about the PRS separating it from public and non-profit non-market rental housing. PRS units may or may not be subsidized and may or may not have some restrictions on initial 
rent levels for some percentage of the units, as is often the case for new construction that receives some form of subsidy. It is "private" in the sense that it is owned on an entrepreneurial basis as a market commodity that can be freely transferred (sold, traded) to others, locally or globally.

The housing units within the PRS comprises primary and secondary forms of rental housing. The primary rental sector consists of purpose-built rental housing, that is, residential construction developed for the rental housing market, including, but not limited to, multi-unit rental apartment buildings (Canada Mortgage and Housing Corporation, 2016). The secondary rental sector consists of housing that was not originally intended as rental but is made available as rental. This includes detached and semi-detached houses, freehold row/town houses, accessory apartments as separate dwelling units within another structure, and investor-owned units in condominiums which are offered for rent. This distinction is necessary because different laws and policies, from building codes to landlord-tenant regulations, apply to the different types of rental housing (Harris \& Kinsella, 2017; Suttor, 2017).

\section{Trends in the Supply of Private Rental Housing}

A majority of Canada's rental housing is in the larger metropolitan areas. About $40 \%$ of all rentals are in the four largest CMAs of Montréal, Toronto, Calgary, and Vancouver (Figure 20.1). But the concentration is even greater than that given the large population of the Montréal and Toronto metropolitan areas. These two CMAs have one-third of Canada's rental housing. Significant additions to the purpose-built rental stock took place from the 1950s to the 1980s, then levelled off, with some additions in the recent decade. The rental stock data in Figure 20.1 are from the census. It thus captures all types of rental, primary and secondary. Some of the

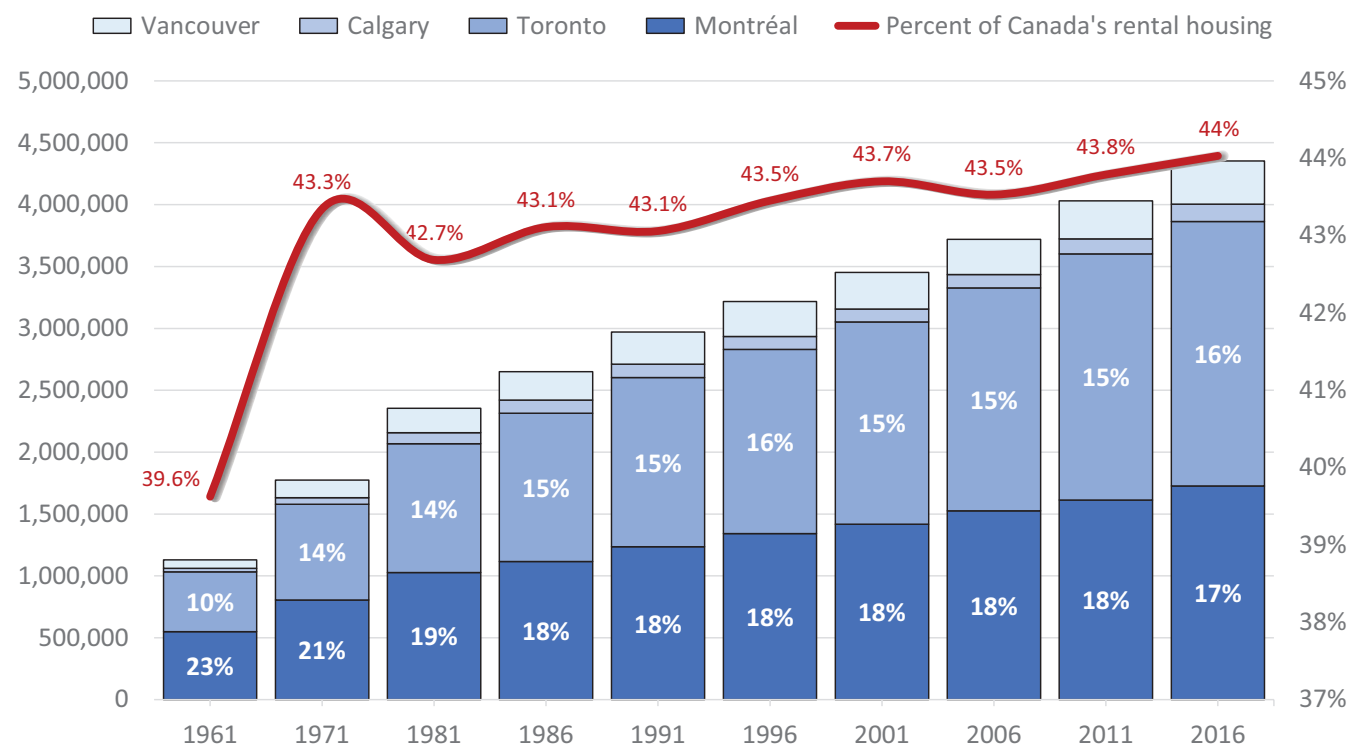

FIGURE 20.1 Rental Housing Total and Percentage of Canada's Rental Housing, 1961-2016. Source: Statistics Canada, Census 1961-2016 and National Household Survey, 2011. 
increase in rentals are apartments in houses, many in basements. Many of these are poor quality (Patterson \& Harris, 2017).

As the rate of homeownership increased after the 1960s, and as the number of households in metropolitan areas increased, the percentage of renters in the four largest metropolitan areas decreased (see Figure 20.2). This is not a decrease in the number of renters, rather a decrease in the share of renters relative to owners. More rental housing was still required given the continuing increase in the population, the decrease in average house sizes, and the need to replace aging housing.

Canada is an exception in terms of the growth in the share of households in the PRS in Anglophone homeownership societies (Chisholm \& Hulchanski, 2019; Maclennan et al., 2019). There has been a decrease in homeownership in the UK, Ireland, the USA, Australia, and New Zealand. The housing markets in these countries were more seriously impacted by the global financial crisis than Canada. Though the trend to an increased share of private renting predates the GFC, it has become more rapid since 2008 (Hulse et al., 2019; Pawson et al., 2017).

As more of the land around the cities in the post-war era was serviced (physical and social infrastructure), most of the land was zoned for low-density homeownership. The combination of more housing supply intended for homeownership and the end of significant PRS supply subsidies by the 1980s, the start of fiscal austerity, represents an explicit public policy abandonment of low- and moderate-income renters. Direct budgetary subsidies and indirect tax system subsidies for the PRS were provided from the mid-1940s to the mid-1980s (Clayton, 2010; Clayton Research Associates, 1998; Department of Finance, 2019; Dowler,

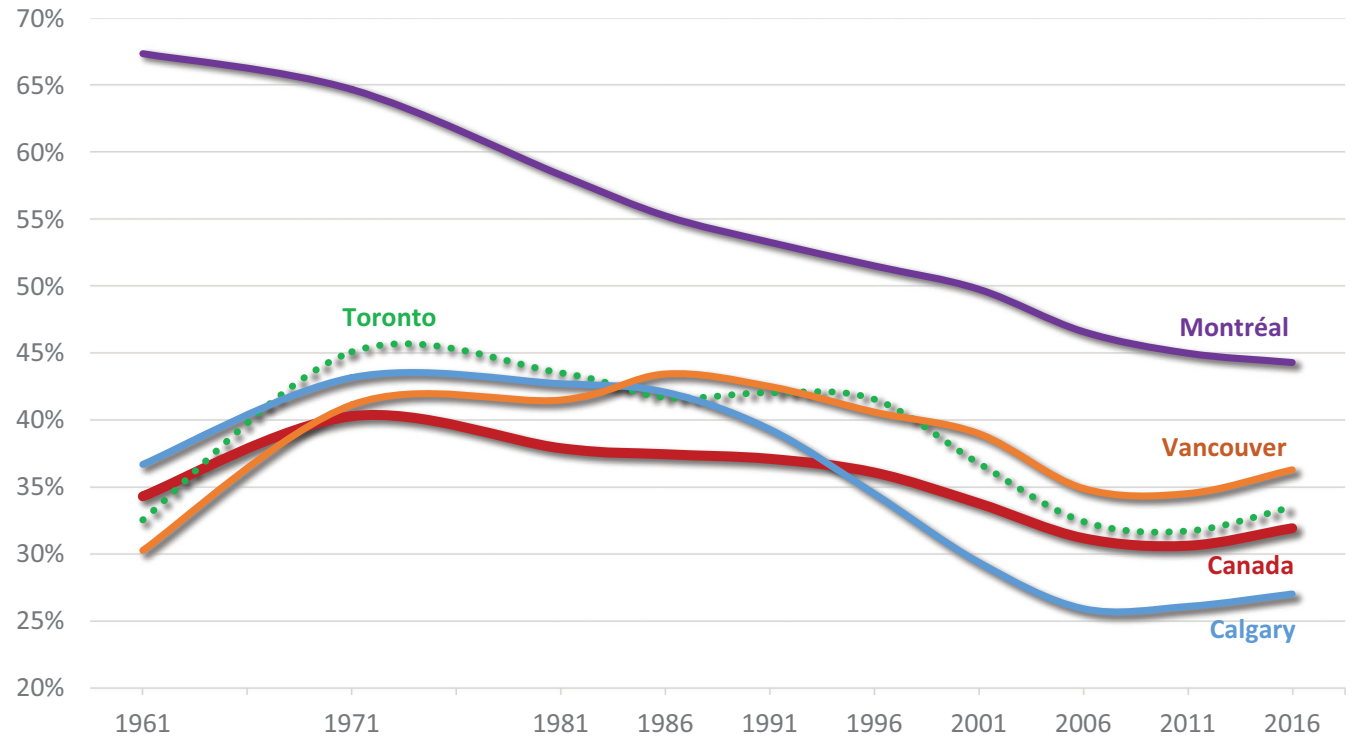

FIGURE 20.2 Rental Housing Percentage, 1961-2016.

Source: Statistics Canada, Census 1961-2016 and National Household Survey, 2011. 


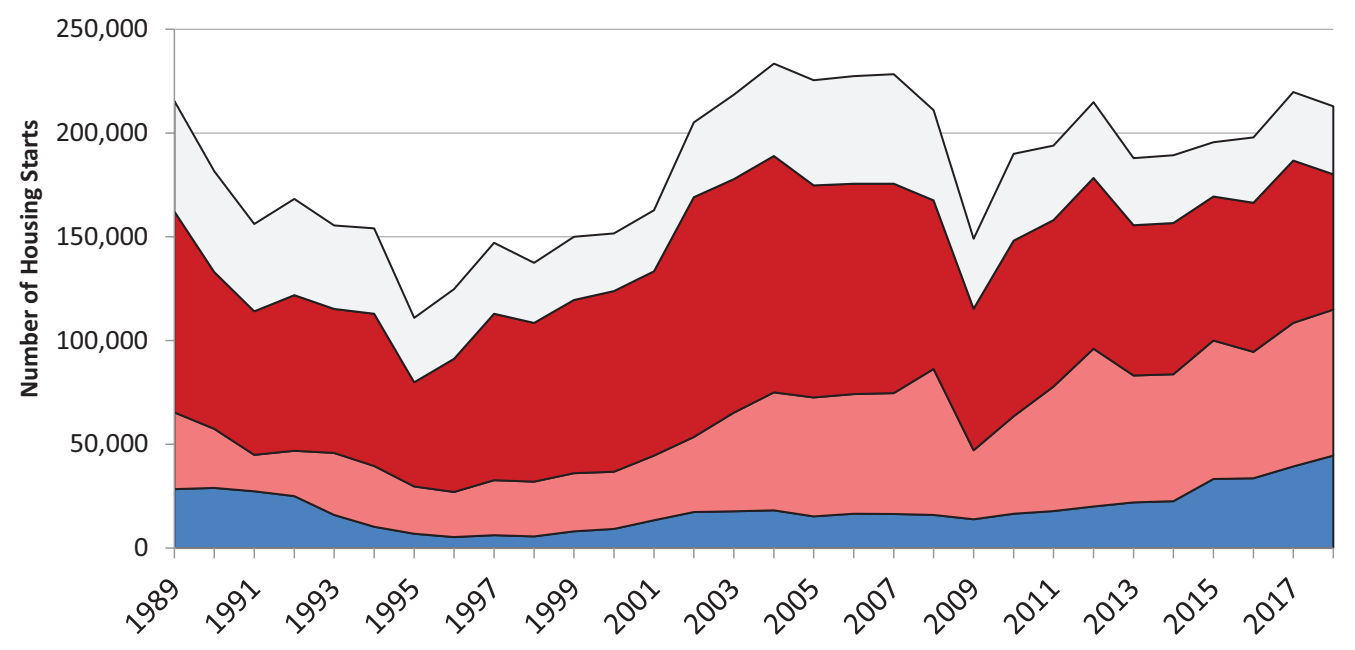

FIGURE 20.3 Housing Starts by Intended Market, 1989-2018.

Note: Canada, cities over 50,000 population, and total. CMHC Starts \& Completions Survey data. Rental refers to dwellings constructed for rental purposes, regardless of who finances the structure (for-profit; non-profit). Some condominium units are investor owned and offered for rent. Ownership here refers to detached and semi-detached houses, and row townhouses.

Source: Statistics Canada, Table: 34-10-0148-01 and CMHC Housing Market Portal.

1983; Hulchanski, 2004). Canada entered the contemporary era of neoliberal public policies about a decade after the US Reagan and the UK Thatcher administrations. The major income support and social housing expenditure cutbacks by the federal and provincial governments came in the 1990s. Subsidies for homeownership were maintained and new ones added. This was not the case for rental housing, whether for the private sector or for the social housing sector.

Over recent decades, housing supply, the construction of new housing nationally, has proceeded at record levels, with only a relatively slight fall due to the GFC. Most of the housing built, however, are intended for the ownership market. As Figure 20.3 indicates, there has been a slight increase in purpose-built rental housing in recent years. Some condominiums are investor-owned and contribute to the PRS stock of housing, at least until they are sold to an owner occupier or converted to short-term tourist rentals (e.g., Airbnb rentals). That is, rentals in condominiums, unlike purpose-built rentals, may not necessarily be rental over the long term.

\section{Condition of Housing in the PRS}

In Canada, about $60 \%$ of rental housing were built prior to the 1980s (Figure 20.4). About $50 \%$ were built during a 50-year period (mid-1940s to mid-1990s) when the federal and some provincial governments were subsidizing both private rental (generally 1945 to 1984) and social rental (mainly 1965-1995). The post-1980 rental housing stock consists of some social housing (until 1995), an increasing number of condominiums for rent, and many informal sector rentals (e.g., secondary suites). 


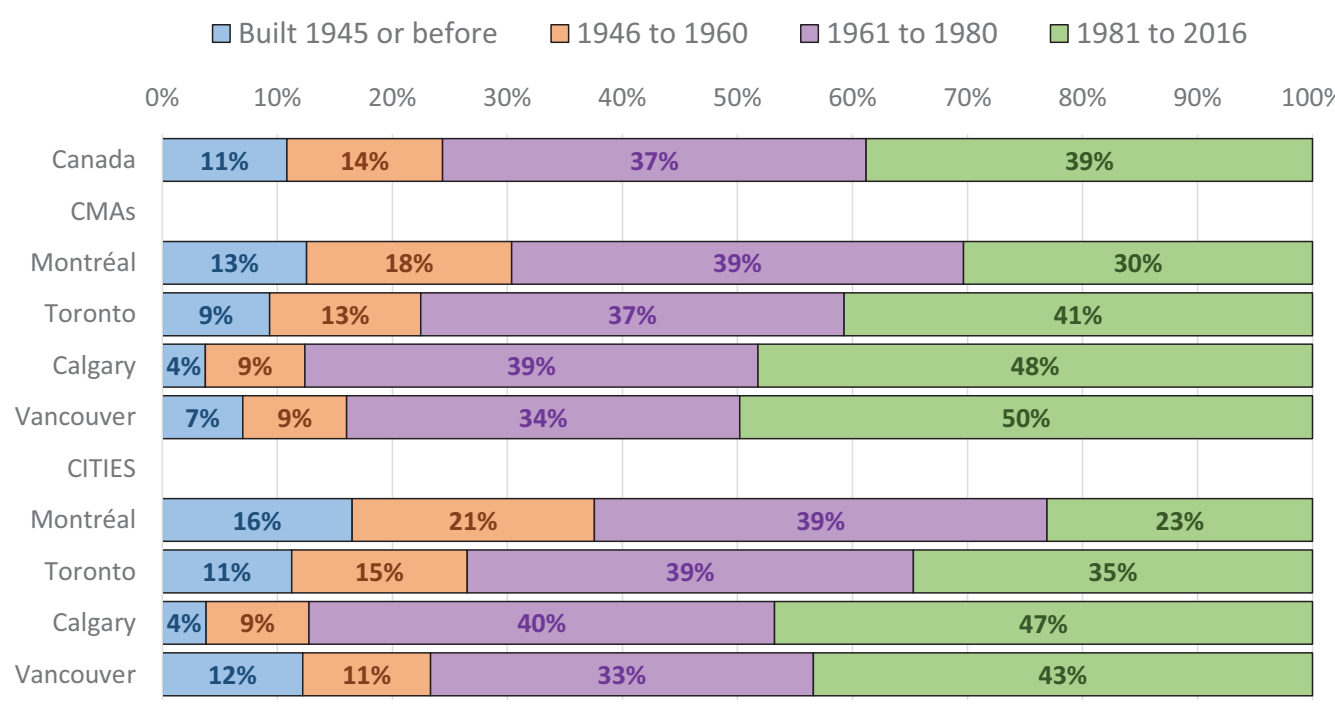

FIGURE 20.4 Age of Rental Housing Stock, 2016.

Note: Period of construction for rented dwellings occupied by usual residents.

Source: Statistics Canada, Census 2016 Data Table 98-400-X2016221 and Custom Tabulation EO2986.

Canada had a modest program for rehabilitation of ageing housing. The Residential Rehabilitation Assistance Program (RRAP) was initiated by the Government of Canada in 1973. It replaced urban renewal, which focused on demolishing existing neighbourhoods in favour of neighbourhood and housing preservation (Falkenhagen, 2001). In the 1970s and 1980s, RRAP funded rehabilitation of about 10,000 units annually. After 1994, more modest funding was provided for about 2,000 units annually (Sutter, 2016).

\section{The Rental Housing Disadvantage Index}

The Rental Housing Disadvantage Index (RHDI) was developed by the Neighbourhood Change Research Partnership to identify specific locations of inadequate rental housing and housing-related distress among tenants in Canada's metropolitan areas (Maaranen, 2019). The RHDI identifies geographic areas with concentrations of low-income renters living in inadequate housing for purposes of further research and potential policy and program intervention.

The RHDI has both similarities and differences with Canada Mortgage and Housing Corporation's measurement of core housing need (CHN) (Pomeroy et al., 2004). CMHC's CHN is based on three housing indicators from the census: adequacy, affordability, and suitability. The RHDI uses these same three measures but adds low-income renters. In addition, the RHDI has a geographic focus, at the census tract level, so as to identify and map the location of the concentrations of rental housing disadvantage by level of severity.

The RHDI is calculated as the average of four location quotient indicators that measure the concentration of disadvantage at the census tract (CT) level in comparison to the CMA average. Only census tracts with $25 \%$ or more rental housing are included. 
The four indicators are:

- Inadequate housing defined as the percentage of rented occupied dwellings requiring major repairs.

- Unaffordable housing defined as the percentage of renter households paying $50 \%$ or more of income on rent.

- Unsuitable housing is defined as the percentage of renter households with a bedroom shortfall based on the number of bedrooms, number of household members, and household composition (gender, age).

- Low-income status is defined as the percentage of renter households with before-tax total income that is below half (50\%) of the CMA median household income (all households, owners, and renters).

The RHDI is a measure of the spatial concentration of housing-related disadvantage experienced by people who rent. It reveals where inadequate, unaffordable, unsuitable rental housing and income deficiencies coexist in significant proportions in particular neighbourhoods. Figure 20.5 provides a summary of the percentage of CT (as a proxy for neighbourhoods) that have high and low rental housing disadvantage. The City of Toronto has the highest share of census tracts with high RHDI (50\%).

The chart needs to be understood in conjunction with the size of the rental stock in each CMA and in the context of the relative size of the central city within each CMA. Renters in each of these four CMAs comprise the following share of households:

- Montréal CMA: 765,000 renters, 44\% of CMA households, $64 \%$ of these renters live in the City, $63 \%$ of City households are renters.

- Toronto CMA: 715,000 renters, 33\% of CMA households, $74 \%$ live in the City, $47 \%$ of City households are renters.

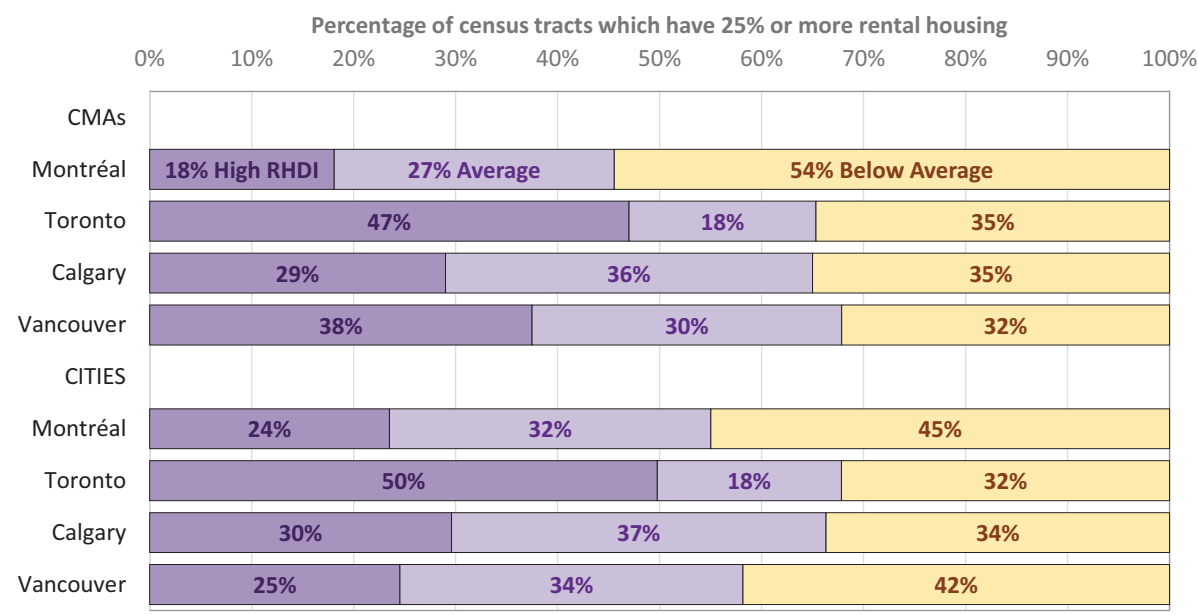

FIGURE 20.5 Rental Housing Disadvantage Index Distribution, 2016.

Note: Disadvantage Index (RHDI) is the average of four location quotient indicators which measure the concentration of disadvantage at the census tract level in comparision to the census metropolitan area (CMA) average: adequacy, affordability, suitability and low-income intensity. Below average disadvantage refers to RHDI < 1.0; average disadvantage refers to RHDI 1.0 to 1.19 , high disadvantage refers to RHDI 1.2 or more. Figures exclude CTs with less than 25\% rental housing in 2016.

Source: Statistics Canada, Custom Tabulation EO2986, Census 2016. 
- Calgary CMA: 140,000 renters, 27\% of CMA households, 95\% live in the City, 29\% of City households are renters.

- Vancouver CMA: 151,000 renters, 36\% of CMA households, 43\% live in the City, 49\% of City households are renters (2016 Census).

\section{Housing Tenure Income Inequality}

The income gap between renters and owners was about 20\% in the 1960s (Hulchanski, 1988). It has increased to about $90 \%$ nationally, with some variation among the larger metropolitan areas (Figure 20.6). The housing tenure income gap has paralleled the growth in income inequality. For the PRS, this has great significance. The private rented sector never could house low-income households, other than in substandard housing (down filtering of the aging rentals). Gentrification and ever rising market values of land and housing in successful metropolitan areas have led to filtering and rising rents for even poor-quality rentals. The end of federal PRS supply subsidy programs in the early 1980s coincided with the rise in income inequality and neoliberal fiscal austerity affecting programs that once provided better income support and services to lower-income, mainly renter, households. Markets respond to effective market demand (people with money), not to social need. The growing gap in incomes between owners and renters has been an inducement for more "apartment buildings" to be condominiums, intended for the ownership market, rather than rental. The fact that some condominium units are investor owner and rented is positive but further harms the prospects for investment in new purpose-built rentals. Rents in new rental buildings are higher than existing average rents. Condominium units for rent satisfy some or most of the market demand for new and more expensive rentals.

Another implication of growing income inequality is the increasing age of homeowners compared to renters. Though Canada's homeownership rate has been relatively stable, owners are increasing from an aging demographic. The rental sector is housing younger households

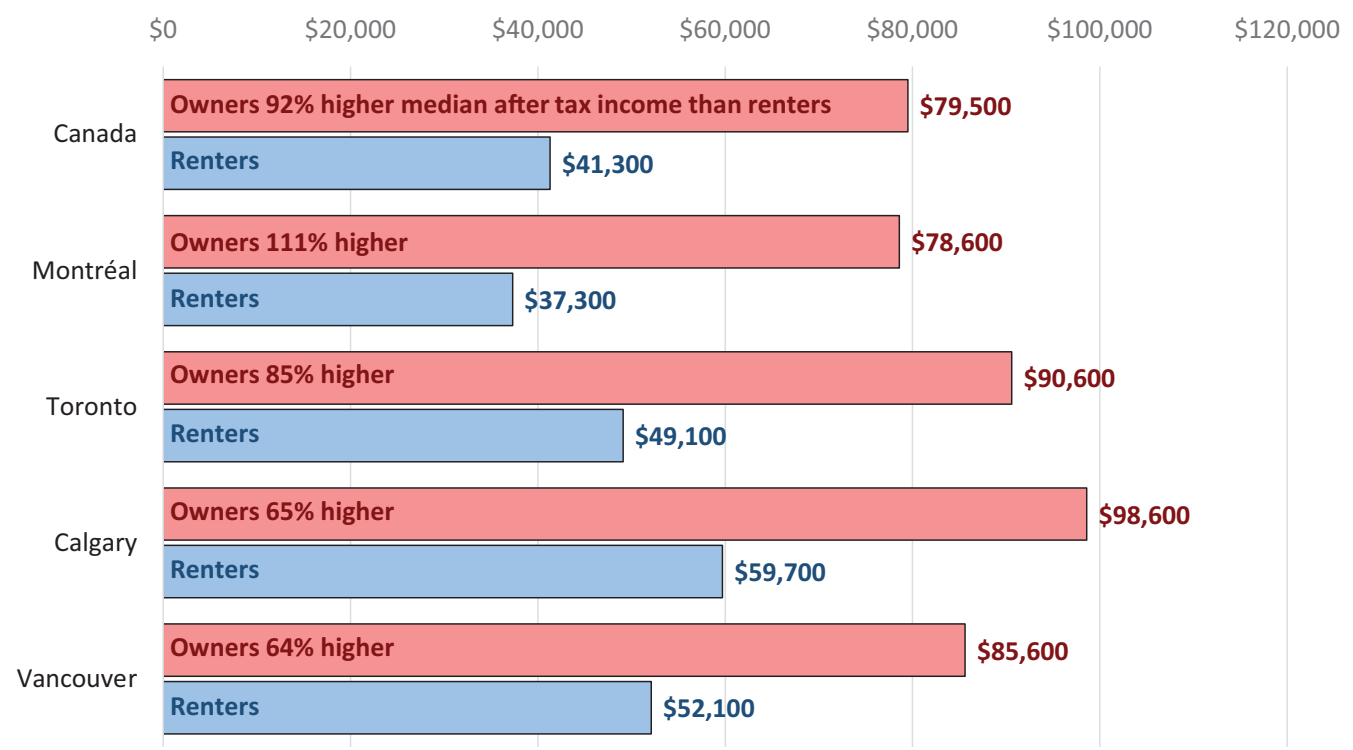

FIGURE 20.6 Owner/Renter Household Income Gap, 2017.

Source: CMHC, Real Median Aer Tax Income of Owners and Renter Households, 2006-2017 Data Tables. www.cmhc-schl.gc.ca/en/data-and-research/data-tables/household-characteristics.. 
TABLE 20.1 Housing Tenure in Canada by Age Group, 1981-2016

\begin{tabular}{|c|c|c|c|c|c|c|}
\hline \multicolumn{5}{|c|}{ Homeownership Rate } & \multirow{2}{*}{$\frac{\text { Difference }}{1981-2016(\%)}$} & \multirow{2}{*}{$\frac{\text { Difference }}{2006-2016(\%)}$} \\
\hline Age Group & $1981(\%)$ & $1991(\%)$ & $2006(\%)$ & $2016(\%)$ & & \\
\hline $15-34$ & 43.9 & 41.9 & 44.4 & 43.1 & -0.7 & -1.3 \\
\hline $35-44$ & 72.2 & 68.9 & 68.1 & 66.3 & -5.9 & -1.8 \\
\hline $45-54$ & 76.2 & 75.3 & 74.1 & 73.3 & -3 & -0.9 \\
\hline $55-64$ & 73.7 & 76.1 & 76.6 & 76.3 & 2.5 & -0.3 \\
\hline $65-74$ & 66.1 & 71 & 76 & 76.3 & 10.1 & 0.2 \\
\hline 75 and over & 57.4 & 59.3 & 67.7 & 72.3 & 14.8 & 4.6 \\
\hline Age 15 and over & 62.3 & 63.3 & 67.4 & 67.8 & 5.5 & 0.4 \\
\hline \multicolumn{5}{|c|}{ Rental Housing Rate } & Difference & Difference \\
\hline Age Group & $1981(\%)$ & $1991(\%)$ & $2006(\%)$ & $2016(\%)$ & $1981-2016(\%)$ & $2006-2016(\%)$ \\
\hline $15-34$ & 56.1 & 58.1 & 55.6 & 56.3 & 0.2 & 0.8 \\
\hline $35-44$ & 27.8 & 31.1 & 31.9 & 33.2 & 5.4 & 1.3 \\
\hline $45-54$ & 23.8 & 24.7 & 25.9 & 26.3 & 2.5 & 0.4 \\
\hline $55-64$ & 26.3 & 23.9 & 23.4 & 23.4 & -2.9 & 0 \\
\hline $65-74$ & 33.9 & 29 & 24 & 23.5 & -10.4 & -0.5 \\
\hline 75 and over & 42.6 & 40.7 & 32.3 & 27.6 & -15 & -4.7 \\
\hline Age 15 and over & 37.7 & 36.7 & 32.6 & 31.8 & -5.9 & -0.8 \\
\hline
\end{tabular}

Note: The probability of each age group living in home ownership or rental tenure. Primary household maintainers age 15 and over only.

Source: Statistics Canada, Census Public Use Microdata 1981, 1991, 2006. Census 2016 Data Table 98-400-X2016226

than in the past (see Table 20.1). This does not add to the prospects for significant private sector investment in purpose-built rental.

\section{Key Policy Characteristics of Canada's Post-WWII PRS}

Canada's PRS has the following four key characteristics that shape, mainly constrain, the supply and demand mechanism in what ought to be a functioning market.

\section{(1) New PRS supply subsidies: Very limited since 1984}

Most of the post-WWII supply of new purpose-built rental housing was subsidized until 1984 and had favourable tax treatment until early 1970s.

In 2001, the federal government announced an Affordable Housing Framework in collaboration with provinces and territories, cost shared on a 50/50 basis, to re-engage in providing some housing assistance. The federal funds, compared to levels prior to the mid-1990s, were very modest. Funding could be used for new rental supply, assisted homeownership, rehabilitation, and rent allowances. Subsidies for rental housing supply were in the form of one-time capital grants. In contrast to the approximately 20,000 social housing units that were funded annually from the mid-1960s to the mid-1990s, the Affordable Housing Framework subsidies resulted in 4,000-6,000 market rental or social rental units per year. In 2011, the new Investment in Affordable Housing (IAH), 2011-2018, provided a very modest $\$ 3.7$ billion over ten years for construction, renovation, and affordability assistance. Funding ended in 2018-2019, with only \$0.3 billion in 2019-2020 (Canada, Parliamentary Budget Officer, 2019:14). 
In 2017, the federal government released a document outlining a number of new housing programs scheduled to begin in 2019-2020 (Canada Mortgage and Housing Corporation, 2017). Details of the proposed spending on the various promised programs over the tenyear housing strategy have been provided by the independent Parliamentary Budget Officer in a 2019 report, Federal Program Spending on Housing Affordability. Loans and some modest subsidies to encourage construction of purpose-built rental are significant for the housing strategy.

\section{(2) Housing tenure neutrality: Only homeownership matters}

Canada does not have a tenure-neutral housing subsidy system. Homeownership is consistently favoured and promoted by Canadian governments (Hulchanski, 2004). As in other Western nations, there has been a shift away from direct subsidies for addressing social needs typical of the post-war welfare state to an asset-based approach promoting social well-being through wealth accumulation (Doling \& Ronald, 2010; Housing Europe, 2019; Ronald, 2008). Homeownership provides the opportunity for asset-based welfare serving as yet another rationale for homeownership as the focus of Canada's national housing policy (Walks, 2016).

Federal annual subsidies for homeownership equal to about $\$ 7$ billion; social non-market rental housing has a stream of subsidies that in recent decades reached $\$ 2.5$ billion (inflation adjusted), and is now decreasing to about $\$ 0.5$ billion over the coming ten years because few new social housing units are being funded. Tenants in the PRS receive little or nothing in financial terms from the federal government. The lack of a tenure-neutral housing subsidy system, one favouring ownership, means that higher-income renters are encouraged to become owners. While it may be beneficial at an individual household level, it means that for the PRS, new rental buildings, which have higher rents than older existing rentals, have a smaller pool of renters able to pay the higher rents. Homeownership in Canada receives the following subsidies:

- Non-taxation of capital gains on principal residence, since $1972=\$ 6$ billion in 2018

- $\quad$ First-Time Home Buyers Tax Credit, since $1991=\$ 110$ million in 2018

- $\quad$ GST Rebate for New Housing, since $1991=\$ 550$ million in 2018

- Home Buyers Plan (use of $\$ 35,000$ of RRSP for down payment) $=\$ 15$ million per year admin cost

- $\quad$ First-Time Home Buyer Incentive, Budget $2019=\$ 40$ million per year admin cost

- $\quad$ Shared Equity Mortgage Provider Fund, Budget $2019=\$ 20$ million per year.

(Source: Canada, Finance Department, 2019; Parliamentary Budget Officer, 2019)

\section{(3) Housing inequality by housing tenure}

The income gap between renters and owners is now about 100\%. Renters in all parts of Canada have about half the income of homeowners (Figure 20.6). There is some variation among metropolitan areas, but not very much. The small percentage of high-income renters, who can afford rent levels that new rental buildings require, are either on their way to homeownership saving for a down payment, or are having most of their demand for higher-quality rental apartments being met by the investor-owned rental condominium units. In Toronto, about $40 \%$ of condominium units are rentals, equalling about $20 \%$ of the city's rental stock (CMHC, 2018). While there are many impediments to new private sector rental supply, the fact is that most renters constitute a social need for adequate rentals they can afford, rather than generating effective market demand that encourages new market rental supply. 


\section{(4) Rental only municipal zoning}

Canadian municipalities have engaged in residential density regulations (via zoning bylaws) since the 1920s. Canada had rental only zoning until the late 1960s when legislation allowing condominium ownership was introduced (Hulchanski, 1988; Steele, 1993). Condominium legislation allowed apartment buildings to be built as either registered condominiums intended for the ownership market (though investor-owned units within some condominiums are rentals), or as conventional purpose-built rental buildings.

Given the gap in incomes of renters and owners, condominium developers can outbid rental developers for building sites, and in doing so raise property values in general. Market rents thus need to be even higher in new rental buildings if they are to be financially viable. This helps explain why so few primary (purpose-built) private sector rental housing have been built since the end of significant PRS supply tax subsidies in the 1970s and the last supply subsidy program, the Canada Rental Supply Plan, was terminated in 1984. The income gap between owners and renters was smaller in the three decades following the Second World War, there were no condominiums to compete for the higher-density residentially zoned building sites, and there were significant direct and indirect (tax system) subsidies for private rental supply. Those conditions no longer exist.

\section{Conclusion}

What is next for the private rented sector in the medium and long term? There are plenty of interrelated issues and complicated relationships: market demand, social need, supply, subsidies, location, quality, choice, distribution, regulations, discrimination, affordability, investors, owners, management, and the PRS's institutional role within the housing system and the related social welfare system in general. The PRS should not continue to be treated as a low priority part of Canada's housing system.

There are plenty of actors - politicians, policy-makers, civil society actors, real estate investors, engaged citizens - who need to better understand and rethink the nature and role of the PRS within Canada's housing system. Can we make progress on building a more inclusive housing system if we do not make the system more tenure-neutral in terms of the policies and subsidies benefitting homeownership versus renting? Canada's housing system needs to (1) stimulate adequate rental housing production; (2) help produce a mix of rental housing choice (location, size, quality); and (3) assist those who cannot afford adequate, appropriate rental housing. How likely is it that Canada's housing policy will change significantly over the coming decade?

A reason for being pessimistic about PRS progress is that housing is such a major and profitable, wealth-enhancing part of so many key societal institutions that change, while not impossible, will meet with strong resistance from those who benefit most from the current, almost-purely, market-based housing system. The broad institutional context in which the housing system operates is relatively stable. For several decades there has been little change in the size, functions, and relationships between housing tenures in Canada. Change is not impossible, but it will meet with strong resistance by those who have been able to define the rules of the housing game in their favour and have the financial and political resources to continue doing so.

Unless there is significant change in Canadian housing policy, which is mainly up to the federal and provincial cabinets, that is, those who actually have the power to change the rules of the game, existing negative trends in the PRS will not only continue but be intensified. Among 
the trends, fewer renters will become owners as ownership becomes more difficult; there will be increased overcrowding in existing ageing rentals as individuals and households double-up; landlord/tenant relations will become more difficult consuming more legal resources of all parties and society; the political debate over stricter rent regulations will be even more turbulent; there will be continuing deterioration in the quality of and need for rehabilitation of an aging stock of rental housing; there will continue to be inadequate levels of new purpose-built (primary vs secondary) rental housing; and more renters will find themselves in unsafe, unregulated, illegal, and exploitative forms of residential rental situations. This will further residualize rental housing. Residualization here refers to an ongoing process and a policy direction that leads to rental housing, and tenants in general, in a high homeownership and highly unequal (income and wealth) nation like Canada, becoming an increasingly low status, stigmatized, and undesirable part of the housing system, subject to financially exploitation and displacement by local and global financial forces.

What policy options should be considered for the PRS? The following are within provincial and federal jurisdiction (there is, in addition, much for municipalities to do in planning and zoning).

- Significant incentives (subsidies) for new supply in the PRS as well as for new social housing supply.

- Attract large institutional investors to the PRS with targeted tax incentives.

- Provide significant rehabilitation subsidies for the existing rental stock.

- Regulate rent increases and end vacancy decontrol given the decades-long market failure in the PRS (failure of affordable market supply).

- Provide and enforce better security of tenure to tenants in all forms of rental housing.

- Seriously address and punish housing discrimination.

- Educate landlords and tenants about their rights and responsibilities.

- Require full disclosure of the beneficial owners of real estate and the source of investment funds.

Though these may seem reasonable to many, Canada's housing system is built on five main principles. These benefit the minority who profit from the system as it is, and each is an impediment to a just and inclusive housing system: (1) rely almost exclusively on the market mechanism; (2) privilege homeownership and generally ignore private and social renting; (3) avoid investment in non-market forms of housing; (4) allow continued financialization of, and speculation with, Canada's stock of housing and real estate in general; and (5) deny that Canadians have the justiciable human right to adequate housing. This set of principles leads to a housing system that is an effective mechanism for increasing wealth for some, providing overly expensive and often inadequate housing for others, institutionalizing mass homelessness, and increasing economic inequality. Canada has the resources and the knowledge to do better.

\section{Acknowledgements}

This research was supported by the Neighbourhood Change Research Partnership, funded by a partnership grant from the Social Sciences and Humanities Research Council of Canada. Data analysis and preparation of the charts were by Richard Maaranen, Data Analyst Research Associate, Neighbourhood Change Research Partnership, Factor-Inwentash Faculty of Social Work, University of Toronto. 


\section{References}

Aalbers, M.B. (2016). The financialization of housing: A political economy approach. Abingdon: Routledge.

August, M., \& Walks, A. (2018). Gentrification, suburban decline, and the financialization of multifamily rental housing: The case of Toronto. Geoforum, 89, 124-136.

Bacher, J.C. (1993). Keeping to the marketplace: The evolution of Canadian housing policy. Montréal: McGillQueen's University Press.

Boudreau, J.A., Keil, R., \& Young, D. (2009). Changing Toronto: Governing urban neoliberalism. Toronto: University of Toronto Press.

Bourne, L.S. (1981). The geography of housing. London: Arnold.

Bourne, L.S. (1986). Recent housing policy issues in Canada: A retreat from social housing? Housing Studies, 1(2), 122-128.

Bunting, T., Walks, A.R., \& Filion, P. (2004). The uneven geography of housing affordability stress in Canadian metropolitan areas. Housing Studies, 19(3), 361-393.

Canada, Department of Finance (2019). Report on federal tax expenditures: Concepts, estimates and evaluations. Ottawa: Government of Canada.

Canada Mortgage and Housing Corporation (2001). Understanding private rental housing investment in Canada. Ottawa: CMHC, Research Highlight, Socio-economic Series 42.

Canada Mortgage and Housing Corporation (2016). A profile of purpose-built rental housing in Canada. Ottawa: Government of Canada.

Canada Mortgage and Housing Corporation (2017). Canada's national housing strategy: A place to call home. Ottawa: Government of Canada.

Canada, Parliamentary Budget Officer (2019). Federal program spending on housing affordability. Ottawa.

Chisholm, S., \& Hulchanski, J.D. (2019) Canada's housing story. In Maclennan, D., Pawson, H., Gibb, K., Chisholm, S., \& Hulchanski, J.D., editors. Shaping futures: Changing the housing story, Australia, Britain, Canada. Glasgow: Policy Scotland, University of Glasgow, 21-28.

Clayton, F. A. (2010). Government subsidies to homeowners versus renters in Ontario and Canada. Toronto: Federation of Rental-Housing Providers of Ontario and Canadian Federation of Apartment Associations.

Clayton Research Associates (1998). Economic impact of federal tax legislation on the rental housing market in Canada. Toronto: Canadian Federation of Apartment Associations.

Crook, T. (1998). The supply of private rented housing in Canada. Netherlands Journal of Housing and the Built Environment, 13(3), 327-352.

Crook, T., \& Kemp, P. A. (Eds). (2014). Private rental housing: Comparative perspectives. Cheltenham: Edward Elgar Publishing.

Doling, J., \& Ronald, R. (2010). Home ownership and asset-based welfare. Journal of Housing and the Built Environment, 25(2), 165-173.

Doling, J., \& Richard, R. (2019). "Not for housing” housing: Widening the scope of housing studies. Critical Housing Analysis, 6(1), 22.

Dowler, R. G. (1983). Housing-related tax expenditures: An overview and evaluation. Toronto: University of Toronto, Centre for Urban and Community Studies.

Falkenhagen, D. (2001). The history of Canada's residential rehabilitation assistance program (RRAP). Ottawa: Canada Mortgage and Housing Corporation.

Gibb, K., Pawson, H., \& Hulchanski, J.D. (2019). Private renting. In Maclennan, D., Pawson, H., Gibb, K., Chisholm, S., \& Hulchanski, J.D., editors. Shaping futures: Changing the housing story, Australia, Britain, Canada. Glasgow: Policy Scotland, University of Glasgow, 55-68.

Granath Hansson, A., \& Lundgren, B. (2019). Defining social housing: A discussion on the suitable criteria. Housing, Theory and Society, 36(2), 149-166.

Grisdale, S. (2019). Displacement by disruption: Short-term rentals and the political economy of "belonging anywhere" in Toronto. Urban Geography, 1-27. www.tandfonline.com/doi/ full/10.1080/02723638.2019.1642714

Hackworth, J., \& Moriah, A. (2006). Neoliberalism, contingency and urban policy: The case of social housing in Ontario. International Journal of Urban and Regional Research, 30(3), 510-527.

Haffner, M., et al. (2010) Universalistic, particularistic and middle way approaches to comparing the private rental sector. International Journal of Housing Policy, 10(4), 357-377. 
Harris, R., \& Kinsella, K. (2017). Secondary suites: A survey of evidence and municipal policy. The Canadian Geographer/Le Géographe Canadien, 61(4), 493-509.

Housing Europe (2019). The state of housing in the EU 2019. Brussels: The European Federation of Cooperative and Social Housing.

Hulchanski, J.D. (1988). The evolution of property rights and housing tenure in post-war Canada: Implications for housing policy. Urban Law and Policy, 9(2), 135-156.

Hulchanski, J.D. (2004). What factors shape Canadian housing policy? The intergovernmental role in Canada's housing system. In Young, R., \& Leuprecht, C., editors. Municipal-federal-provincial relations in Canada. Montréal: McGill-Queens University Press, 221-250.

Hulchanski, J.D., \& Shapcott, M. (2004). Finding room: Policy options for a Canadian rental housing strategy. Toronto: University of Toronto, Centre for Urban and Community Studies.

Hulse, K., Morris, A., \& Pawson, H. (2019). Private renting in a home-owning society: Disaster, diversity or deviance? Housing, Theory and Society, 36(2), 167-188.

Kalman-Lamb, G. (2017). The financialization of housing in Canada: Intensifying contradictions of neoliberal accumulation. Studies in Political Economy, 98(3), 298-323.

Ley, D. (2015). Global China and the making of Vancouver's residential property market. International Journal of Housing Policy, 17(1), 15-34.

Maaranen, R. (2019). The NCRP Rental Housing Disadvantage Index (RHDI): What it is and how it is calculated, 2016 census update. Toronto: University of Toronto, Neighbourhood Change Research Partnership.

Macdonald, D. (2019). Unaccommodating: Rental housing wage in Canada. Ottawa: Canadian Centre for Policy Alternatives.

Maclennan, D., Pawson, H., Gibb, K., Chisholm, S., \& Hulchanski, D. (2019). Shaping futures: Changing the housing story, Australia, Britain, Canada. Glasgow: Policy Scotland, University of Glasgow.

Madden, D., \& Marcuse, P. (2016). In defense of housing. New York: Verso.

Miron, J.R. (1995). Private rental housing: the Canadian experience. Urban Studies, 32(3), 579-604.

Oxley, M., \& Smith, J. (2012). Housing policy and rented housing in Europe. Abingdon: Routledge.

Pomeroy, S., Dalton, T., Stegman, M. A., \& Wilcox, S. (2004). An international comparison of housing need indicators. Ottawa: Canada Mortgage and Housing Corporation.

Pomeroy, S., \& Falvo, N. (2013). Pragmatism and political expediency: Housing policy in Canada under the Harper regime. In Doern, G. B., \& Stoney, C., editors. How Ottawa spends, 2012-2013: The Harper majority, budget cuts, and the new opposition. Montréal: McGill-Queen's University Press, 184-195.

Patterson, A., \& Harris, R. (2017). Landlords, tenants, and the legal status of secondary suites in Hamilton, Ontario. The Canadian Geographer/Le Géographe Canadien, 61(4), 540-549.

Pawson, H., Hulse, K., \& Morris, A. (2017). Interpreting the rise of long-term private renting in a liberal welfare regime context. Housing Studies, 32(8), 1062-1084.

Rogers, D., \& Koh, S. Y. (2017). The globalisation of real estate: The politics and practice of foreign real estate investment. International Journal of Housing Policy, 17(1), 1-14.

Ronald, R. (2008). The ideology of home ownership: Homeowner societies and the role of housing. Basingstoke: Palgrave Macmillan.

Steele, M. (1993). Conversions, condominiums and capital gains: The transformation of the Ontario rental housing market. Urban Studies, 30(1), 103-126.

Suttor, G. (2016). Still renovating: A history of Canadian social housing policy. Montréal: McGill-Queens University Press.

Suttor, G. (2017). Basement suites: Demand, supply, space, and technology. The Canadian Geographer/Le Géographe Canadien, 61(4), 483-492.

Suttor, G.F. (2009). Rental paths from postwar to present: Canada compared. Toronto: University of Toronto, Cities Centre.

Tsenkova, S., \& Witwer, M. (2011). Bridging the gap: Policy instruments to encourage private sector provision of affordable rental housing in Alberta. Canadian Journal of Urban Research, 20(1), 52-80.

van der Heijden, H. (2013). West European housing systems in a comparative perspective. Amsterdam: IOS Press.

Walks, A. (2014a). Canada's housing bubble story: Mortgage securitization, the state, and the global financial crisis. International Journal of Urban and Regional Research, 38(1), 256-284.

Walks, A. (2014b). From financialization to sociospatial polarization of the city? Evidence from Canada. Economic Geography, 90(1), 33-66. 
288 J. David Hulchanski

Walks, A. (2016). Homeownership, asset-based welfare and the neighbourhood segregation of wealth. Housing Studies, 31(7), 755-784.

Walks, A., \& Clifford, B. (2015). The political economy of mortgage securitization and the neoliberalization of housing policy in Canada. Environment and Planning A: Economy and Space, 47(8), 1624-1642.

Wolfe, J.M. (1998). Canadian housing policy in the nineties. Housing Studies, 13(1), 121-134. 